\title{
RESEARCH
}

Open Access

\section{Efficacy of soil solarization on black root rot disease and speculation on its leverage on nematodes and weeds of strawberry in Egypt}

Mahfouz M. M. Abd-Elgawad ${ }^{*}$, Ibrahim E. Elshahawy and Farid Abd-El-Kareem

\begin{abstract}
Background: Strawberry (Fragaria ananassa Duch.) is an economically important crop in Egypt. Yet complex black root rot disease of strawberry caused by Fusarium solani, Rhizoctonia solani, and Pythium sp. can cause considerable yield losses. Therefore, this study aimed at evaluating different aspects of soil solarization against this disease. Such an evaluation would better be viewed in the context of other beneficial effects of soil solarization on nematodes and weeds.
\end{abstract}

Materials/methods: Growth agar disks, growth suspension, and resting stages of strawberry black root rot fungi were evaluated at different temperatures and exposure times using digital hot water bath. Cloth bags artificially infested with single fungal species were buried into the soil before soil solarization at soil depths of 1-10, 11-20, and 21-30 cm at three spots of each plot for each of the abovementioned fungi for 3, 6, or 9 weeks. The disease incidence and severity in solarized and un-solarized soil was compared with the application of the fungicide Actamyl. Effects of soil solarization on nematodes and weeds were also consulted.

Results: The lethal temperature to $F$. solani, Pythium sp., and $R$. solani was 58,58 , and $56^{\circ} \mathrm{C}$, respectively when exposure time was $1 \mathrm{~min}$. Chlamydospores were killed at $62{ }^{\circ} \mathrm{C}$ while sclerotia were killed at $58{ }^{\circ} \mathrm{C}$ in hot water for 1 min. Maximum soil temperature in solarized soil was raised by 15,14 , and $12^{\circ} \mathrm{C}$ at depths of $1-10,11-20$, and 21-30 cm as compared with non-solarized soil. Solarization for 3, 6, and 9 weeks significantly reduced the disease incidence and severity and increased the strawberry yield. Complete reduction in total count of all tested fungi was obtained after 9 weeks at all tested depths. A review of collective soil pest and pathogen control via solarization documented its beneficial application.

Conclusion: The study may exploit hot months in Egypt for soil solarization against the serious root rot disease either singly or in an integrated pest management program.

Keywords: Black root rot, Plant pathogen control, Soil solarization, Strawberry

\footnotetext{
*Correspondence: mahfouzian2000@yahoo.com

Plant Pathology Department, National Research Centre, Giza, Egypt
} 


\section{Background}

Strawberry (Fragaria ananassa Duch.) is globally one of the most economically important crops. It is grown under a wide range of climatic conditions as wild and cultivated plants producing small delicious fruits (Kurze et al. 2001). It is favored worldwide for the unique flavor and valuable macronutrients (Bianco et al. 2009). Yet strawberry black root rot ranks high among common diseases that can cause considerable yield losses in Egypt (El-Shemy et al. 2013). This disease is caused by several soil-borne fungal pathogens (Fang et al. 2012; Ahmed and El-Fiki 2017) such as Fusarium oxysporum (Juber et al. 2014), Macrophomina phaseolina (Hutton et al. 2013), Pythium spp. (Abdel-Sattar et al. 2008), Phytophthora spp. (Mingzhu 2011), and Rhizoctonia spp. (Fang et al. 2013). This complex disease is characterized by feeder rootlet killing, plant deterioration and blackening of the main root system as well as a decline in vigor and productivity of the plant stand causing a decrease in the crop yield (Abdel-Sattar et al. 2008; Fang et al. 2012; Ceja-Torres et al. 2014).

Soil solarization using transparent polyethylene plastic placed on moist soil during the hot months before planting usually increases soil temperature to levels lethal to many soil-borne plant pathogens, weeds, and nematodes (Primo and Cartia 2001; Abd-El-Kareem et al. 2004; Culman et al. 2006; Farag-Eman and Fotouh 2010). Hence, the present study was designed to test the effect of subjecting such fungal pathogens which cause the root rot disease to various categories of raised temperature under various forms, mainly solarization. However, being the only disease among other diseases and pests that is examined herein by solarization, such a study might be construed as imperfect from a collective soil pest and pathogen control or strawberry yield increase perspective. Therefore, in addition to evaluating the effect of soil solarization for different periods against strawberry black root rot and fruit yield (or for reducing populations of black root rot causing fungi in the soil, thus enhancing plant health), we briefly reviewed the beneficial effects of solarization on plantparasitic nematodes (PPN) and weeds.

\section{Materials and methods}

\section{Fungal pathogens and plant material}

Pathogenic isolates of Fusarium solani, Rhizoctonia solani, and Pythium sp., the most obvious causal agents of black root disease of strawberry plants (Abd-El-Kareem et al., 2019), were kindly provided by Plant Pathology Department, National Research Centre, Giza, Egypt. Strawberry seedlings (cv. Festival) were obtained from Vegetable Crops Research Department, Agricultural Research Centre, Giza, Egypt.
Testing of hot-water treatments on viability of black root rot fungi

Viability of agar disks with mycelia and resting stages of $R$. solani, F. solani, and Pythium sp. was examined according to the method described by Whiting et al. (2001). Growth agar disks, growth suspension, and resting stages of strawberry black root rot fungi were evaluated at different temperatures and exposure times using digital hot water bath (Neslab GP-300 Series Constant Temperature Bath, Union City, CA). Screw-cap glass vials, $20 \mathrm{~cm}$ long and $20 \mathrm{~mm}$ in diameter, containing 20 $\mathrm{ml}$ sterilized water were placed in water path at different temperatures. Disks of agar with mycelia and spores, 6$\mathrm{mm}$ diameter, were cut from the grown edge of 10-dayold cultures of R. solani, F. solani, and Pythium sp. growing on potato dextrose agar (PDA) medium. Agar disks were transferred to screw-cap glass vials, $20 \mathrm{~cm}$ long and $20 \mathrm{~mm}$ in diameter, containing $20 \mathrm{ml}$ sterilized water placed in water path at $25,50,52,54,56$, and 58 ${ }^{\circ} \mathrm{C}$, for different exposures time, i.e., $1,10,20$, and 30 min. These agar disks were then dried using sterilized filter paper and transferred into petri-plates containing PDA medium. Five screw-cap glass vials and 3 disks per each were used for each treatment. Viability of mycelia from agar disk that had been subjected to previous temperatures with different exposure times was assessed by planting treated disks on PDA medium and incubated at $25^{\circ} \mathrm{C}$ for 5 days. Radial colony diameter was measured.

\section{Preparation of fungal inocula}

Inocula of R. solani, F. solani, and Pythium sp. were prepared by culturing each species on $50-\mathrm{ml}$ potato dextrose broth (PDB) medium in 250-ml Erlenmeyer flasks for 15 days at $25-27^{\circ} \mathrm{C}$ and each fungal inoculum was prepared as follows: inoculum of $F$. solani was prepared from the growing upper solid layers and colony forming units (cfu) were adjusted to $10^{6} \mathrm{cfu} / \mathrm{ml}$ using hemocytometers' slide, where soil infestation was done at $50 \mathrm{ml} /$ $\mathrm{kg}$ soil (Elad and Baker 1985). Inoculum $R$. solani was prepared from the growing upper solid layers which were washed and air-dried with sterilized filter paper layers. The air-dry mycelium was blended in distilled water to obtain inocula pieces of 1-2 $\mathrm{mm}$ in diameter. Soil infestation was done at $2 \mathrm{~g}$ dry mycelium $/ \mathrm{kg}$ soil (Al-Mahareeq 2005). Pythium sp. inoculum was similarly prepared and propagules were adjusted to $10^{6} / \mathrm{ml}$. Soil infestation was done at $50 \mathrm{ml} / \mathrm{kg}$ soil (Lu et al. 2004).

\section{Soil infestations with black root rot fungi}

Sandy-loam soils were sterilized at $120^{\circ} \mathrm{C}$ for $1 \mathrm{~h}$. Sterilized soils were singly infested with inoculum of $R$. solani, F. solani, or Pythium sp. as mentioned before. Artificially infested soils were put into cloth bags at 1 $\mathrm{kg}$ infested soil/ bag. 
Mulching soil with transparent polyethylene sheets

Three solarization periods, i.e., 3, 6, and 9 weeks were applied. Soil solarization started at the beginning of the last week of June 2017. All plots were irrigated to field capacity and 4 plots $(3 \mathrm{~m} \times 9 \mathrm{~m})$ were covered with 200 $\mu \mathrm{m}$ thick transparent polyethylene sheets for 3,6 , or 9 weeks and then removed.

\section{Buried cloth bags in infested soil}

Cloth bags similarly infested with single species were buried into the soil before soil solarization at soil depths of $1-10,11-20$, and $21-30 \mathrm{~cm}$ at three spots of each plot for each of the abovementioned fungi and solarization periods.

\section{Efficacy of soil solarization on soil temperatures}

Average of maximum and minimum soil temperatures in solarized and non-solarized soil was recorded weekly using Thermo-couples during solarization period at soil depths of $1-10,11-20$, and $21-30 \mathrm{~cm}$ to estimate the thermal inactivation potential of solarization.

\section{Quantification of black root rot fungi}

Cloth bags infested with pathogenic fungi were buried in the soil before soil mulching as mentioned before. After removing the polyethylene sheets, the buried bags of each certain level in either solarized or un-solarized plots were collected. Total count of pathogenic fungi in solarized and un-solarized soil was compared with their count before soil mulching. Total count of pathogenic fungi was done according to Porras et al. (2007). The fungal colonies per gram of dry soil were calculated. The resulting reduction was counted as follows:

$\%$ Reduction $=[($ No. of colonies in control - No. of colonies in treatment)/No. of colonies in control $] \times 100$

\section{Field experiment}

Field plots $(3 \mathrm{~m} \times 8 \mathrm{~m})$ at El-Qalioubia governorate, Egypt, were irrigated to field capacity and 4 plots were similarly covered with $200-\mu \mathrm{m}$ thick transparent polyethylene sheets. The field was highly infested with strawberry black root fungi. Experiments were conducted under natural-infested soil in plots each comprised of 8 rows $(32$ holes/row and one seedling were sown in each hole) in a randomized complete block design with three replicates (plots) for each treatment. Strawberry seedlings were transplanted in well-drained loamy clay soil to a depth of $10 \mathrm{~cm}$ in October 2017 and uprooted at the end of May 2018. Irrigation and nutrients such as phosphorus, nitrogen, and potassium were added as recommended (El-Shemy et al. 2013).

\section{Treatments}

Solarization periods of 3,6 , and 9 weeks were tested to study their effect on strawberry black root rot and yield relative to the control (un-solarized soil) under field conditions. Solarization started at the beginning of the last week of June 2017. Actamyl (3 g/L) fungicide (active ingredient: thiophanate-methyl) was applied for comparison.

\section{Disease incidence and severity and yield estimate}

Disease incidence was calculated 100 days after transplanting as follows:

$\%$ disease incidence $=$ (number of infected plants $/$ total number of plants) $\times 100$

Disease severity was similarly recorded according to Morocko (2006) as follows:

$0=$ plant well developed, no disease symptoms; $1=$ no visible symptoms on above-ground parts, $25 \%$ of roots discolored; 2 = plant slightly stunted, black necrosis on petiole bases, $26-50 \%$ of roots discolored; $3=$ plant stunted, black necrosis on petiole bases, yellowing and death of outer leaves, $51-75 \%$ of roots discolored; $4=$ plant severely stunted, outer leaves collapsed, younger leaves bluish green and wilting, $>75 \%$ of roots discolored; 5 = plant dead.

Disease severity $\%=\frac{\left.\sum \text { (Disease grade } \times \text { number of plants in each grade }\right)}{\text { Total number of plants } \times \text { highest disease grade }} \times 100$

Accumulated strawberry yield (tons/feddan) for each treatment was determined. Statistical analysis: Tukey test for multiple comparisons among means was utilized (Neler et al. 1985).

\section{Results}

Hot-water treatments

Viability of agar disks with mycelia and resting stages of R. solani, F. solani, and Pythium sp. was tested to determine the lethal temperature of the pathogenic fungi. Results in Table 1 reveal that increasing exposure time and/or temperature could block growth of the tested

Table 1 Viability of mycelia agar disks of strawberry black root rot fungi as affected by hot water at different temperatures and exposure times

\begin{tabular}{|c|c|c|c|c|c|c|c|c|c|c|c|c|}
\hline \multirow{3}{*}{$\begin{array}{l}\text { Hot } \\
\text { water } \\
\left({ }^{\circ} \mathrm{C}\right)\end{array}$} & \multicolumn{12}{|c|}{ Exposure time (minutes) } \\
\hline & \multicolumn{4}{|c|}{ F. solani } & \multicolumn{4}{|c|}{ Pythium sp } & \multicolumn{4}{|c|}{ R. solani } \\
\hline & 1 & 10 & 20 & 30 & 1 & 10 & 20 & 30 & 1 & 10 & 20 & 30 \\
\hline 25 & + & + & + & + & + & + & + & + & + & + & + & + \\
\hline 50 & + & + & + & + & + & + & + & + & + & + & + & + \\
\hline 52 & + & + & + & + & + & + & + & + & + & + & + & + \\
\hline 54 & + & + & + & + & + & + & + & + & + & + & - & - \\
\hline 56 & + & - & - & - & + & + & - & - & - & - & - & - \\
\hline 58 & - & - & - & - & - & - & - & - & - & - & - & - \\
\hline
\end{tabular}

(+) Indicate growth, (-) indicate no growth 
fungi. The lethal temperatures to $F$. solani, Pythium sp., and $R$. solani were 58,58 , and $56{ }^{\circ} \mathrm{C}$ respectively at 1 min of exposure time.

\section{Effect of different exposure times and temperatures on resting stage viability}

Results in Table 2 indicate the effect of different exposure times and temperatures on resting stage germination of strawberry root rot fungi under laboratory conditions. Chlamydospores were more resistant to high temperature as they were killed at $62{ }^{\circ} \mathrm{C}$ but sclerotia were killed at 58 for $R$. solani when exposed to hot water for one minute.

\section{Effect of soil solarization on soil temperatures}

Averages of maximum and minimum soil temperatures in solarized and non-solarized soil were recorded. Results in Table 3 indicate that maximum temperatures in solarized soil increased by 15,14 , and $12{ }^{\circ} \mathrm{C}$ at depths of $1-10,11-20$, and $21-30 \mathrm{~cm}$ of soil surface as compared with un-solarized soil. The highest temperatures were 56,52 , and $46{ }^{\circ} \mathrm{C}$ at the three depths, respectively.

\section{Effect on total count of black root rot fungi in soil}

Results in Table 4 indicate that fungal populations decreased in both mulched and un-mulched soils at the end of the experiment. However, solarization for 6 and 9 weeks was more effective in reducing the pathogens population. Complete reduction in total count of the tested fungi was obtained after 9 weeks at the three solarized depths. Meanwhile, solarization for 6 weeks caused a complete reduction in the total count only at a depth of $1-10$ and $11-20 \mathrm{~cm}$.

Effect of solarization on strawberry black root rot disease Results in Table 5 show that all tested solarization periods significantly reduced the strawberry black root rod disease incidence and severity. The most effective

Table 2 Resting stage viability of strawberry black rot fungi as affected by hot water temperatures and exposure times

\begin{tabular}{|c|c|c|c|c|c|c|c|c|}
\hline \multirow{4}{*}{$\begin{array}{l}\text { Hot } \\
\text { water } \\
\left({ }^{\circ} \mathrm{C}\right)\end{array}$} & \multicolumn{8}{|c|}{ Exposure time } \\
\hline & \multicolumn{4}{|c|}{ Chlamydospores } & \multicolumn{4}{|c|}{ Sclerotia } \\
\hline & \multicolumn{4}{|c|}{ F. solani } & \multicolumn{4}{|c|}{ R. solani } \\
\hline & 1 & 10 & 20 & 30 & 1 & 10 & 20 & 30 \\
\hline 25 & + & + & + & + & + & + & + & + \\
\hline 52 & + & + & + & + & + & + & + & + \\
\hline 54 & + & + & + & + & + & + & - & - \\
\hline 56 & + & + & + & + & + & + & - & - \\
\hline 58 & + & + & + & + & - & - & - & - \\
\hline 60 & + & + & + & - & - & - & - & - \\
\hline 62 & - & - & - & - & - & - & - & - \\
\hline
\end{tabular}

(+) Indicate growth, (-) indicate no growth
Table 3 Effect of soil solarization on soil temperatures

\begin{tabular}{llll}
\hline Soil category & Depth & $\begin{array}{l}\text { Maximum } \\
\text { temperatures }\left({ }^{\circ} \mathrm{C}\right)\end{array}$ & $\begin{array}{l}\text { Minimum } \\
\text { temperatures }\left({ }^{\circ} \mathrm{C}\right)\end{array}$ \\
\hline Solarized soil & $1-10$ & $56 \mathrm{a}$ & $38 \mathrm{a}$ \\
& $11-20$ & $52 \mathrm{~b}$ & $35 \mathrm{~b}$ \\
& $21-30$ & $46 \mathrm{c}$ & $33 \mathrm{C}$ \\
& $1-10$ & $41 \mathrm{~d}$ & $27 \mathrm{~d}$ \\
Un-solarized & $11-20$ & $38 \mathrm{e}$ & $24 \mathrm{e}$ \\
soil & $21-30$ & $34 \mathrm{e}$ & $21 \mathrm{f}$
\end{tabular}

Figures with the same letter in a column are not significantly different $(P \leq$ 0.05) using Tukey test

solarization periods were 6 and 9 weeks which reduced the disease incidence and severity by $87.4,84.6,88.4$, and $87.2 \%$, respectively. Solarization for 3 weeks had a moderate effect.

\section{Effect of solarization on strawberry yield}

Results in Table 6 show that all tested solarization periods significantly increased the strawberry yield. The most effective solarization periods were 6 and 9 weeks which increased the yield by 107.7 and $115.4 \%$, respectively. Solarization for 3 weeks had moderate effect.

\section{Discussions}

Soil solarization proved effective for healthy strawberry cultivation in terms of reducing strawberry root rot disease incidence and severity as well as increasing strawberry fruit yield under different aspects in the current study. These included three different species of pathogenic fungi each at three soil depths. The present results are in agreement with those of Katan et al. (1976) and Katan (1980) who demonstrated that the population of soil-borne fungi F. oxysporum, $R$. solani, and Sclerotium rolfsii were reduced by 62 to $100 \%$ at 5 to 25 -cm depths in solarized soil. Reduction in disease incidence/severity and increase in obtained yield due to soil solarization were reported by many investigators (Katan 1980; Osman et al. 1986; Abd-El-Kareem et al. 2004; Culman et al. 2006; Farag-Eman and Fotouh 2010). Pullman et al. (1981) presented a detailed study on thermal death of three soil-borne plant pathogens as affected by time and temperature of the treatment. They found that the inability of organisms to tolerate high temperatures is related to an upper limit in the degree of fluidity of membranes beyond which breakdown of membrane function may be associated with membrane instability and the sustained inactivation of respiratory enzymes (Sundarum 1986). Also, changes occur in the structure of the soil, insoluble mineral substances available for plant and microbial growth, and in the populations of soil-borne microorganisms during heat treatments of soil (Chen and Katan 1980; Stapleton and DeVay 1984; 
Table 4 Percentage reduction in pathogenic fungi at three soil depths as affected with different periods of solarized and unsolarized soil under field conditions

\begin{tabular}{|c|c|c|c|c|c|}
\hline \multirow[t]{2}{*}{ Treatments } & \multirow{2}{*}{$\begin{array}{l}\text { Solarized } \\
\text { periods } \\
\text { (weeks) }\end{array}$} & \multirow{2}{*}{$\begin{array}{l}\text { Soil } \\
\text { depths } \\
\text { (cm) }\end{array}$} & \multicolumn{3}{|c|}{ Reduction in black root rot fungi \% } \\
\hline & & & F. solani & R. solani & Pythium sp. \\
\hline \multirow[t]{9}{*}{ Solarized soil } & \multirow[t]{3}{*}{3} & $1-10$ & 72 & 75 & 73 \\
\hline & & $11-20$ & 62 & 66 & 64 \\
\hline & & $21-30$ & 45 & 51 & 45 \\
\hline & \multirow[t]{3}{*}{6} & $1-10$ & 100 & 100 & 100 \\
\hline & & $11-20$ & 100 & 100 & 100 \\
\hline & & $21-30$ & 82 & 100 & 86 \\
\hline & \multirow[t]{3}{*}{9} & $1-10$ & 100 & 100 & 100 \\
\hline & & $11-20$ & 100 & 100 & 100 \\
\hline & & $21-30$ & 100 & 100 & 100 \\
\hline \multirow[t]{9}{*}{ Un-solarized soil } & \multirow[t]{3}{*}{3} & $1-10$ & 20 & 22 & 23 \\
\hline & & $11-20$ & 10 & 11 & 9.5 \\
\hline & & $21-30$ & 8 & 11 & 8 \\
\hline & \multirow[t]{3}{*}{6} & $1-10$ & 40 & 46 & 41 \\
\hline & & $11-20$ & 24 & 32 & 21 \\
\hline & & $21-30$ & 10 & 22 & 13 \\
\hline & \multirow[t]{3}{*}{9} & $1-10$ & 65 & 68 & 66 \\
\hline & & $11-20$ & 48 & 52 & 44 \\
\hline & & $21-30$ & 32 & 35 & 33 \\
\hline
\end{tabular}

Figures with the same letter in a column are not significantly different $(P \leq 0.05)$ using Tukey test

Stapleton et al. 1985). These changes that affect the inoculum density of plant pathogens and their aggressiveness and survival are probably not limited to the rot disease. Moreover, crop yield increase due to solarization is not exclusively and definitely attributed to the control of pathogens and weeds but rather to a combination of mechanisms. Plant growth increased in solarized soil without pests and pathogens (Stapleton and DeVay 1984). It could be that immeasurable or undetectable pathogens and pests such as PPN are also controlled. Also, solarization may increase some soluble nutrients such as calcium, nitrogen, and magnesium and make them more available to plants in solarized soil. A third assumption is that beneficial microorganisms such as actinomycetes, mycorrhizal fungi, and species of Trichoderma can survive the solarization process or recolonize the soil rapidly (Stapleton et al. 1985; Kishore et al. 2008).

In this context, soil temperatures increase to lethal levels for many other soil-borne plant pathogens such as PPN and weeds especially during summer months (Elmore et al. 1997; Primo and Cartia 2001; Abd-ElKareem et al. 2004; Culman et al. 2006; Farag-Eman and Fotouh 2010). Hence, the expected increase in temperature with climate change can reinforce the expansion of other alternatives to methyl bromide rather than programs in Egypt that are mostly limited to the evaluation of chemical treatment and biocontrol agents.

Table 5 Black root rot disease of strawberry plants as affected with different periods of solarized and un-solarized soil under field conditions

\begin{tabular}{|c|c|c|c|c|c|}
\hline \multirow[t]{2}{*}{ Treatments } & \multirow{2}{*}{$\begin{array}{l}\text { Solarized } \\
\text { periods } \\
\text { (weeks) }\end{array}$} & \multicolumn{4}{|c|}{ Black root rot disease } \\
\hline & & Disease incidence & Reduction \% & Disease severity & Reduction \% \\
\hline \multirow[t]{3}{*}{ Solarized soil } & 3 & $18.0 \mathrm{~b}$ & 58.1 & $12.0 \mathrm{~b}$ & 69.2 \\
\hline & 6 & $5.4 c$ & 87.4 & $6.0 c$ & 84.6 \\
\hline & 9 & $5.0 \mathrm{c}$ & 88.4 & $5.0 \mathrm{c}$ & 87.2 \\
\hline Actamyl $3 \mathrm{~g} / \mathrm{L}$ & 0.0 & 8.0 & 81.4 & 9.0 & 76.9 \\
\hline Un-solarized soil & 9 & $43.0 \mathrm{a}$ & 0.0 & $39.0 \mathrm{a}$ & 0.0 \\
\hline
\end{tabular}

Figures with the same letter in a column are not significantly different $(P \leq 0.05)$ using Tukey test 
Table 6 Strawberry yield as affected by different periods of solarized and un-solarized soil under field conditions

\begin{tabular}{llll}
\hline Treatments & $\begin{array}{l}\text { Solarization } \\
\text { (in weeks) }\end{array}$ & Strawberry yield & \\
\cline { 3 - 4 } & & Yield (tons/feddan) & Increase \% \\
\hline Solarized soil & 3 & $9.5 \mathrm{~b}$ & 46.2 \\
& 6 & $13.5 \mathrm{a}$ & 107.7 \\
& 9 & $14.0 \mathrm{a}$ & 115.4 \\
Actamyl 3 g/L & 0 & $9.5 \mathrm{~b}$ & 46.2 \\
Un-solarized soil & 0 & $6.5 \mathrm{C}$ & 0.0 \\
\hline
\end{tabular}

Figures with the same letter in a column are not significantly different $(P \leq$ 0.05) using Tukey test

Both progressive phasing out of available chemical nematicides and expected heavier root-knot nematode infestations with warmer climate change should further materialize solarization as an imperative component in integrated pest management (IPM). Candido et al. (2008) found that yearly solarization is needed for rootknot nematodes (RKN) control of greenhouse tomato and melon as very susceptible hosts but two- or threeyearly applications can effectively control weeds. Raising thermal-efficiency films or integration with other PPN control approach can extend the residual impacts of solarization concerning RKN on strawberry. Twoconsecutive year solarization had greatly suppressed RKN and increased yield of tomato and melon (Candido et al. 2008). Samtani et al. (2012) found that steam + solarization treatments were so effective in weed control that both together were similar to combined fumigation.

Generally, plasticulture technologies for strawberry cultivation proved effective against PPNs in Egypt (Mahdy and Midan 2011; Abd-Elgawad 2019). When colored polyethylene sheets (transparent, red, black, green, and blue) were used in such a technology, the best reduction of RKN occurred in transparent sheet relative to the others (Bakr et al. 2013). Plasticulture considerably reduced population levels of numerous PPN species (Sauerborn et al. 1990).

\section{Conclusion}

Under the warm weather conditions of Egypt and expected increase in temperature with potential climate change, solarization is an effective and safe alternative for methyl bromide and other banned chemicals for the management of strawberry pests and diseases. Its reduction of strawberry root rot disease incidence and severity, as well as increase strawberry fruit yield collectively with its control of other pests and pathogens reported in the abovementioned references can offer a satisfactory tool for IPM programs of strawberry; so further feasible studies of such programs are warranted.

\section{Abbreviations}

cfu: Colony forming units; IPM: Integrated pest management; PPN: Plantparasitic nematodes; PDA: Potato dextrose agar; PDB: Potato dextrose broth

\section{Acknowledgements}

This study was supported in part by the US-Egypt Project cycle 17 (no. 172) entitled "Preparing and evaluating IPM tactics for increasing strawberry and citrus production."

\section{Authors' contributions}

All authors participated in the development, implementation, and subsequently writing of the research plan. All authors read and approved the final manuscript.

\section{Funding}

Financial support made by US-Egypt Project fund for Project cycle 17 (no. 172) and National Research Centre, Egypt, is gratefully acknowledged.

\section{Availability of data and materials}

The datasets used and/or analyzed during the current study are available from the corresponding author on reasonable request.

Ethics approval and consent to participate

Not applicable.

Consent for publication

Not applicable.

\section{Competing interests}

The authors declare that they have no competing interests.

Received: 31 July 2019 Accepted: 19 November 2019

Published online: 05 December 2019

\section{References}

Abd-Elgawad MMM (2019) Plant-parasitic nematodes of strawberry in Egypt: a review. Bull. NRC 43:7. https://doi.org/10.1186/s42269-019-0049-2

Abd-El-Kareem F, Elshahawy IE, Abd-Elgawad MMM (2019) Effectiveness of silicon and silicate salts for controlling black root rot and induced pathogenesisrelated protein of strawberry plants. Bull. NRC 43:91. https://doi.org/10.1186/ s42269-019-0139-1

Abd-El-Karem F, Abdallah MA, El-Gamal NG, El-Mougy NS (2004) Integrated control of lupin root rot disease in solarized soil under greenhouse and field condition. Egypt J Phytopathol 32(1-2):49-63

Abdel-Sattar MA, El-Marzoky HA, Mohamed Al (2008) Occurrence of soilborne diseases and root knot nematodes in strawberry plants grown on compacted rice straw bales compared with naturally infested soil. J Plant Prot Res 48(2):223-235

Ahmed MFA, El-Fiki IAI (2017) Effect of biological control of root rot diseases of strawberry using Trichoderma spp. Middle East J Appl Sci 7:482-492

Al-Mahareeq FAA (2005) Biological control of Rhizoctonia solani and Sclerotium rolfsii by using local isolates of Trichoderma spp. M Sc Thesis, Fac Graduate Studies, An-Najah Nat Univ, Nablus, Palestine, p 93

Bakr RA, Mahdy ME, Mousa EM (2013) Efficacy of soil solarization and postplanting mulch on control of root-knot nematodes. Pak J Nematol 31(1): $71-76$

Bianco L, Lopez L, Scalone AG, Di Carli M, Desiderio A, Benvenuto E, Perrotta G (2009) Strawberry proteome characterization and its regulation during fruit ripening and in different genotypes. J Proteomics 72:586-607

Candido V, D'Addabbo T, Basile M, Castronuovo D, Miccolis V (2008) Greenhouse soil solarization: effect on weeds, nematodes and yield of tomato and melon. Agron Sustain Dev 28:221-230

Ceja-Torres LF, Mora-Aguilera G, Mora-Aguilera A (2014) Agronomical management influence on the spatiotemporal progress of strawberry dry wilt in Michoacán, Mexico. Afric J Agric Res 9(4):513-520

Chen Y, Katan I (1980) Effect of solar heating of soils by transparent polyethylene mulching on their chemical properties. Soil Sci 130:271-277

Culman SW, Duxbury JM, Lauren JG, Thies JE (2006) Microbial community response to soil solarization in Nepal's rice and wheat cropping system. Soil Biol Biochem 38:3359-3371 
Elad Y, Baker R (1985) Influence of trace amount of cations and siderophoreproducing Pseudomonads on Chlamydospores of Fusarium oxysporum. Phytopath 75:1047-1052

Elmore CL, Stapleton JJ, Bell CE, Devay JE (1997) Soil solarization: a nonpesticidal method for controlling diseases, nematodes, and weeds. Oakland: University of California, Division of Agriculture and Natural Resources, Publication 21377.

El-Shemy AA, Khafagy YS, Al-Genteery AMM (2013) Cultivation and production of strawberry. Techn issue no. 9/2013, General Directorate of Agricultural Culture, Egyptian Ministry of agriculture, Giza, 135 p. (in Arabic)

Fang XD, Finnegan PM, Barbetti MJ (2013) Wide variation in virulence and genetic diversity of binucleate Rhizoctonia isolates associated with root rot of strawberry in western Australia. PLOS ONE 8(2):e55877

Fang XD, Kuo J, You MP, Finnegan PM, Barbetti MJ (2012) Comparative root colonization of strawberry cultivars Camarosa and Festival by Fusarium oxysporum f. sp. fragariae. Plant and Soil 358:75-89

Farag-Eman SH, Fotouh YO (2010) Solarization as a method for producing fungal-free container soil and controlling wilt and root-rot diseases on cucumber plants under greenhouse conditions. Arch Phytopath Plant Protect 43:519-526

Hutton DG, Gomez AO, Mattner SW (2013) Macrophomina phaseolina and its association with strawberry crown rot in Australia. Int J Fruit Sci 13(1-2): 149-155

Juber KS, Al-Juboory HH, Al-Juboory SB (2014) Fusarium wilt disease of strawberry caused by Fusarium oxysporum f. sp. Fragariae in Iraq and its control. J Exper Biol Agric Sci 2(4):419-427

Katan J (1980) Solar pasteurization of soils for disease control: status and prospects. Plant Dis Reptr 64:450-454

Katan J, Greenberger A, Alon H, Grinstein H (1976) Solar heating by polyethylene mulching for the control of diseases caused by soil-borne pathogens. Phytopath 66:683-688

Kishore M, Singh J, Pandey M (2008) Management of wilt disease caused by Fusarium oxysporum f.sp. lini in linseed through cultural practices. Ann Plant Prot Sci 16:425-427

Kurze S, Dahl R, Bahl H, Berg G (2001) Biological control of fungal strawberry diseases by Serratia plymuthica HRO-C48. Plant Dis 85:529-534

Lu Z, Tombolini R, Woo S, Zeilinger S, Lorito M, Janet K (2004) In vivo study of Trichoderma-pathogen-plant interactions using constitutive and inducible green fluorescent protein reporter systems. Appl Environ Microbiol 70:3073-3081

Mahdy ME, Midan SA (2011) Physiological response of strawberry grown in rootknot nematode infested soil under different safety control applications. Arab Univ J Agric Sci 19:217-231

Mingzhu L (2011) A Multiplex PCR for the detection of Phytophthora nicotianae and $P$. cactorum and a survey of their occurrence in strawberry production areas of Japan. Plant Dis 95(10):1270-1278

Morocko I (2006) Characterization of the strawberry pathogen Gnomonia fragariae, and biocontrol possibilities. Ph D Thesis ISSN 1652-6880, ISBN 91576-7120-6

Neler J, Wassermann W, Kutner MH (1985) Applied linear statistical models. In: Richard D (ed) Regression analysis of variance and experimental design, $2^{\text {nd }}$ edit. Irwin Inc., Homewood, Illionois, pp 117-155

Osman AR, Fahim MM, Sahab AS, Abd El-Kader MM (1986) Soil solarization for the control of lupin wilt. Egypt J Phytopatol 18:75-88

Porras M, Barrau C, Arroyo FT, Santos B, Blanco C, Romero F (2007) Reduction of Phytophthora cactorum in strawberry fields by Trichoderma spp. and soil solarization. Plant Dis 91(2):142-146

Primo PD, Cartia G (2001) Solarization and biofumigation to control Fusarium oxysporum f. sp. melonis. Informatore Agrario 57:55-58

Pullman GS, DeVay JE, Garber RH (1981) Soil solarization and thermal death: a logarithmic relationship between time and temperature for four soil-borne plant pathogens. Phytopath 71:959-964

Samtani JB, Gilbert C, Weber JB, Subbarao KV, Goodhue RE, Fennimore SA (2012) Effect of steam and solarization treatments on pest control, strawberry yield, and economic returns relative to methyl bromide fumigation. HortScience 47(1):64-70

Sauerborn J, Saxena MC, Masri H (1990) Control of faba bean nematodes by soil solarization in Syria. ArabJ Plant Prot 8:38-40

Stapleton JJ, DeVay JE (1984) Thermal components of soil solarization as related to changes in soil and root microflora and increased growth response. Phytopath 74:255-259
Stapleton JJ, Quick J, DeVay JE (1985) Soil solarization: effect on soil properties, crop fertilizers and plant growth. Soil Biol Biochem 17:369-373

Sundarum TK (1986) Physiology and growth of thermophylic bacteria In: Brock TD (ed) Thermophiles General Molecular and Applied Microbiology. Springer Verlag, New York, pp 285-316

Whiting EC, Khan A, Gubler WD (2001) Effect of temperature and water potential on survival and mycelial growth of Phaeomoniella chlamydospora and Phaeoacremonium spp. Plant Dis 85:195-201

\section{Publisher's Note}

Springer Nature remains neutral with regard to jurisdictional claims in published maps and institutional affiliations.

\section{Submit your manuscript to a SpringerOpen ${ }^{\circ}$ journal and benefit from:}

- Convenient online submission

- Rigorous peer review

- Open access: articles freely available online

- High visibility within the field

- Retaining the copyright to your article

Submit your next manuscript at $\boldsymbol{\nabla}$ springeropen.com 